ROCZNIKI HUMANISTYCZNE

Tom LXVIII, zeszyt $10 \quad-\quad 2020$

DOI: http://dx.doi.org/10.18290/rh206810-14

MAŁGORZATA BROŻYNA-RECZKO

\title{
NARZĘDZIA CYFROWE W DYDAKTYCE PRZEKŁADU: ZASOBY LEKSYKALNE ORAZ NARZĘDZIA KORPUSOWE DO EDYCJI TEKSTU
}

\section{WPROWADZENIE}

Niniejszy artykuł stanowi przegląd zasobów leksykalnych (dostępnych online), w tym słowników kolokacji oraz słowników relacji semantycznych, oraz narzędzi korpusowych, które stanowią nieocenioną pomoc podczas dokonywania weryfikacji oraz (post)edycji różnego rodzaju tekstów. Zostaną przedstawione głównie te zasoby oraz narzędzia, które są wykorzystywane do różnego rodzaju analiz, również kontrastywnych, dotyczących języka polskiego i języka angielskiego, gdyż ta para języków stanowi przedmiot niniejszych badań.

Dodatkowo, na potrzeby niniejszego artykułu oraz dalszych prac badawczych z zakresu dydaktyki przekładu, zostało przeprowadzone badanie pilotażowe, którego celem było sprawdzenie, których narzędzi oraz zasobów leksykalnych używają studenci przekładoznawstwa do weryfikacji oraz edycji tekstów. Za materiał badawczy posłużyły fragmenty tekstów prasowych zawierających wyrażenia metaforyczne, gdyż to one bardzo często stanowią problem thumaczeniowy, z którym tłumacz musi się zmierzyć. Interesujące również było to, na jakim etapie i w jakim celu studenci używali odpowiednich słowników oraz narzędzi korpusowych, aby ocenić poprawność przetłumaczonych wyrażeń metaforycznych oraz dokonać pewnych modyfikacji leksykalno-stylistycznych tekstu.

Dr MaŁgorzata Brożyna-Reczko - Uniwersytet Pedagogiczny im. KEN w Krakowie, Katedra Dydaktyki Przekładu; e-mail: malgosiabrozyna1@gmail.com. ORCID: https://orcid.org/0000-00025373-2171. 


\section{KOMPETENCJA WYSZUKIWANIA INFORMACJI}

Współcześnie, w związku z rozwojem nowoczesnych technologii oraz różnorodnością tekstów do tłumaczenia, obserwuje się znaczne poszerzenie roli i zadań tłumacza. Tę wielość ról podkreśla Joanna Dybiec-Gajer („Kompetencje" 167-193) w artykule na temat kompetencji profesjonalnego tłumacza i stwierdza, że zadania, przed którymi staje tłumacz, mogą dotyczyć „inżynierii wielojęzycznej i multimedialnej komunikacji”. Oznacza to, że od tłumacza wymaga się już nie tylko znajomości języków oraz umiejętności samego thumaczenia, wiedzy z zakresu odpowiedniej dziedziny, ale także innych powiązanych ze sobą umiejętności, takich jak umiejętności zawodowe, metodologiczne oraz techniczne (Gouadec).

Ta złożoność i różnorodność w zakresie wiedzy, umiejętności oraz kompetencji jest widoczna $\mathrm{w}$ modelu kompetencyjnym EMT, opracowanym w 2009 r. z inicjatywy Dyrekcji Generalnej ds. Tłumaczeń Pisemnych w celu stworzenia jednolitego europejskiego programu kształcenia tłumaczy pisemnych w ramach edukacji uniwersyteckiej. Do ramowych kompetencji tłumacza zawodowego w programie EMT należą: kompetencja świadczenia usług tłumaczeniowych, kompetencja językowa, kompetencja międzykulturowa, kompetencja zdobywania informacji, kompetencja tematyczna oraz kompetencja technologiczna, która odnosi się do ,umiejętności skutecznego i szybkiego posługiwania się narzędziami elektronicznymi wspomagającymi prace tłumacza" (Dybiec-Gajer, Zmierzyć przekład 79). Warto również zauważyć, że $\mathrm{w}$ tym modelu wyszukiwanie informacji stało się jedną z kluczowych kompetencji tłumacza. Chodzi tu głównie o umiejętność stosowania różnych strategii wyszukiwania informacji, korzystania ze źródeł leksykalnych oraz tworzenia własnych zasobów leksykalnych, słowników czy glosariuszy. Jest to bardzo ważna kompetencja, gdyż - jak pokazują najnowsze badania w przyszłości można się spodziewać, że praca tłumacza w głównej mierze będzie polegać na postedycji oraz weryfikacji tekstu. Ta kompetencja jest mocno dziś opisywana w literaturze przedmiotu oraz zwraca się na nią coraz większą uwagę w kształceniu akademickim, np. na Uniwersytecie Pedagogicznych w Krakowie proponuje się studentom studiów magisterskich specjalizację: Przekładoznawstwo - technologie tłumaczeniowe. Kierunek ten otrzymał w 2019 r. akredytację EMT.

Kompetencja technologiczna jest definiowana również $\mathrm{w}$ innych modelach, np. grupy badawczej PACTE. Określa się ją jako subkompetencję instrumentalną i definiuje jako wiedzę z zakresu nowoczesnych technologii 
oraz narzędzi wspierających pracę tłumacza (Dybiec-Gajer, Zmierzyć przekład 81-83). Zawarta jest również w europejskiej normie dotyczącej świadczenia usług tłumaczeniowych PN-EN 15038 jako kompetencja w zakresie technologii informacyjnej. Dodatkowo warto zauważyć, że w opisywanej normie podkreśla się również umiejętność poszukiwania i przetwarzania informacji (Sekuła 95-108).

Wszystkie wymienione kompetencje są ważne w edukacji tłumacza, dlatego treści oraz ćwiczenia związane $\mathrm{z}$ ich kształceniem powinny stanowić element planu studiów magisterskich. Jak pokazują badania przeprowadzone m.in. przez J. Dybiec-Gajer („Kompetencje” 180), profesjonalni thumacze wskazują na potrzebę uczenia kompetencji technologicznej oraz praktycznych aspektów związanych z pracą tłumacza, w tym umiejętności wyszukiwania informacji. Warto podkreślić, że w procesie tłumaczenia wyszukiwanie i przetwarzanie informacji odgrywa dziś bardzo ważną rolę. Uważa się nawet, że w dobie nowych technologii tłumacz staje się ,użytkownikiem informacji, a także tym, który przetwarza oraz tworzy informację" (Raído 181). Z tego względu coraz więcej uwagi poświęca się kształceniu umiejętności szybkiego i precyzyjnego przeszukiwania, przetwarzania informacji oraz zarządzania informacją. W planach studiów są proponowane kursy, których głównym celem jest rozwijanie u studentów umiejętności korzystania $\mathrm{z}$ informacji (tzw. information skills). Są to np. w Hiszpanii Computer Science (or IT) Applied to Translation, Terminology, Electronic Tools and Resources for Translation, a w Polsce, np. na Uniwersytecie Pedagogicznym w Krakowie, Narzędzia cyfrowe w przektadoznawstwie.

\section{PRZEGLĄD ZASOBÓW LEKSYKALNYCH ORAZ NARZĘDZI DO WYSZUKIWANIA INFORMACJI LEKSYKALNYCH}

Poniżej opisano pokrótce najważniejsze zasoby leksykalne oraz narzędzia do wyszukiwania informacji leksykalnych i semantycznych, które mogą być pomocne w różnego rodzaju zadaniach tłumaczeniowych, również tych związanych z weryfikacją oraz edycją tekstu w języku polskim i w języku angielskim.

Wśród słowników ogólnych języka polskiego warto wymienić Wielki słownik języka polskiego (WSJP), opracowany pod kierunkiem Piotra Żmigrodzkiego, który powstaje od 2007 r. w pracowni Instytutu Języka Polskiego PAN. Warto zwrócić uwagę, że ten słownik nie podaje jedynie informacji o znaczeniu, ale także o sposobie użycia danej jednostki leksykalnej. 
Znajdziemy tam m.in. informacje składniowe, fleksyjne, noty dotyczące normy językowej oraz uzusu, a także listę najczęstszych połączeń wyrazowych $\mathrm{z}$ danym leksemem. Jest to niezwykle przydatne narzędzie w pracy tłumacza oraz weryfikatora, gdyż bardzo często wątpliwości leksykalne dotyczą właśnie połączeń wyrazowych.

Słownikiem, który także zawiera dane na temat kolokacji (dla języka polskiego i języka angielskiego), jest $H A S K$ - baza najczęstszych połączeń wyrazów wygenerowana $\mathrm{z}$ polskich $\mathrm{i}$ angielskich referencyjnych korpusów językowych.

Pomocne mogą okazać się również słowniki relacji semantycznej, tj. Wordnet (dla języka angielskiego), Słowosieć (dla języka polskiego) czy porównywarka wyrazów Kolozaurus. Warto zwrócić uwagę, że w Słowosieci dodatkowo umieszczono informacje na temat synonimów międzyjęzykowych oraz dane dotyczące zabarwienia emocjonalnego danej jednostki leksykalnej.

Jeśli chodzi o narzędzia korpusowe wspomagające tłumaczenie oraz edycję tekstu, to przydatne mogą okazać się wyszukiwarki konkordancji, kolokacji Narodowego Korpusu Języka Polskiego, który jest korpusem referencyjnym. Ponadto zawiera on również funkcję analizy dystrybucyjnej oraz czasowej, co może się okazać przydatne w różnego rodzaju badaniach kontrastywnych. Dla języka angielskiego takim korpusem jest na pewno British National Corpus, dostępny na różnych platformach. Godną polecenia jest $B N C W e b$, gdyż zawiera dokładną instrukcję, jak formułować zapytania, oraz opis wszystkich funkcji. Do analiz socjolingwistycznych dobrym narzędziem może okazać się BNClab.

Konkordancji czy kolokacji można również wyszukiwać w zasobach Internetu i tworzyć zapytania za pomocą wyszukiwarki Google Advanced Search czy WebCorp Live.

Przydatne do weryfikacji mogą okazać się również korpusy paralelne, które są ogólnie dostępne w Internecie, np. Context Reverso. Dużą bazą korpusów jest platforma Sketch Engine, która oprócz korpusów paralelnych (np. DGT, OPUS, EUR-lex) udostępnia dla swoich użytkowników korpusy referencyjne oraz specjalistyczne. W Sketch Engine można również tworzyć własne korpusy. Taką funkcją ma też Korpusomat.

W dobie nowych technologii powstaje coraz więcej zasobów leksykalnych oraz narzędzi do analizy tekstów. Stają się one coraz bardziej przyjazne użytkownikom, zwłaszcza tym niezwiązanym z informatyką czy przetwarzaniem języka naturalnego. 
Warto również zachęcać studentów do poszukiwania nowych narzędzi oraz samodzielnego odkrywania funkcji już istniejących. Nabiorą wówczas pewnego oglądu, jak takie narzędzia działają i które funkcje mogą być pomocne w rozwiązywaniu konkretnych problemów tłumaczeniowych.

\section{OPIS BADANIA PILOTAŻOWEGO}

Badanie zostało przeprowadzone w ramach kursu „Narzędzie cyfrowe w przekładoznawstwie", podczas którego studenci poznali działanie oraz funkcje opisanych powyżej narzędzi oraz zasobów. W badaniu wzięło udział 22 studentów studiów przekładoznawczych, kierunek: tłumaczenie - technologie thumaczeniowe (pierwszy rok studiów magisterskich) na Uniwersytecie Pedagogicznym w Krakowie. Wszyscy ukończyli studia licencjackie z zakresu przekładoznawstwa i są rodzimymi użytkownikami języka polskiego. Zadanie brzmiało następująco:

(...) Below there are 10 extracts from newspapers and magazines already machine translated into the target language. The metaphorical expressions are in bold. Use various corpus and Web-based tools in order to post-edit the selected phrases. Describe in a few steps what your search strategy was. What tools did you use? What particular features? Provide search strings or insert screen shots. Which corpus or tool did you find the most useful in this task?

Obłęd ekonomiczny. To wszystko jednak drobiazg w porównaniu z szaleństwem (...) (Polityka, 9.01.2010)

Economic insanity. But this is all a trifle compared to the madness (...). (Google translate)

Pozostałe przykłady ${ }^{1}$ :

\begin{tabular}{|l|l|}
\hline FRAGMENT TEKSTU ŹRÓDŁOWEGO & TŁUMACZENIE (Google) \\
\hline $\begin{array}{l}\text { The aim would be to give taxpayers some of the benefit } \\
\text { if the banks recovered. (The Times, 7.10.2008) }\end{array}$ & $\begin{array}{l}\text { Celem byłoby przekazanie podatnikom części korzyści, } \\
\text { gdyby banki odzyskały. }\end{array}$ \\
\hline $\begin{array}{l}\text { (...) in order to crunch ailing banks together. (The } \\
\text { Economist, 10-16.10.2009) }\end{array}$ & (...) aby wspólnie zlikwidować słabnące banki. \\
\hline
\end{tabular}

\footnotetext{
1 Studenci otrzymali dłuższe fragmenty tekstów z wytłuszczonymi metaforami, aby lepiej zrozumieć znaczenie badanych wyrażeń metaforycznych oraz określić ich funkcje.
} 


\begin{tabular}{|c|c|}
\hline $\begin{array}{l}\text { Banki nie mogą sobie pozwolić na stratę naszych osz- } \\
\text { czędności, bo z poprzednich lat został im garb kredy- } \\
\text { tów (...) (Gazeta Wyborcza, 4.01.2010) }\end{array}$ & $\begin{array}{l}\text { Banks can not afford to lose our savings, because from } \\
\text { previous years they have been hired by loans. }\end{array}$ \\
\hline $\begin{array}{l}\text { The sell-off came as politicians desperately tried to } \\
\text { soothe bank nerves (...). (The Times, 7.10.2008) }\end{array}$ & $\begin{array}{l}\text { Doszło do wyprzedaży, gdy politycy rozpaczliwie pró- } \\
\text { bowali ukoić nerwy bankowe (...) }\end{array}$ \\
\hline $\begin{array}{l}\text { Should the ECB have done more in the boom to avoid } \\
\text { today's desperate hangover? (The Economist, } 22 \text { - } \\
\text { 28.10.2011) }\end{array}$ & $\begin{array}{l}\text { Czy EBC powinien zrobić więcej w boomie, aby uniknąć } \\
\text { dzisiejszego rozpaczliwego kaca? }\end{array}$ \\
\hline $\begin{array}{l}\text { Otóż pierwszym tego warunkiem jest wyleczenie jego } \\
\text { kadr z choroby mięczaków (...)(Gazeta Wyborcza, } \\
5.08 .2010)\end{array}$ & $\begin{array}{l}\text { Well, the first condition is to cure his frame of mollusc } \\
\text { diseases }(\ldots)\end{array}$ \\
\hline $\begin{array}{l}\text { (...) za historią z gazem stoi fiksacja polityczna? } \\
\text { (Fakt, 9.12.2008) }\end{array}$ & $\begin{array}{l}\text { (...) that there is political fixation behind the history } \\
\text { of gas? }\end{array}$ \\
\hline $\begin{array}{l}\text { (...) to rozwiązanie prowadzi do patologii (...) } \\
\text { (Rzeczpospolita, } 4.01 .2010)\end{array}$ & (...) this solution leads to pathology (...) \\
\hline
\end{tabular}

Zadanie studentów polegało zatem na zrozumieniu znaczenia wyrażenia metaforycznego w tekście wyjściowym, ocenie przetłumaczonych maszynowo metafor, ewentualnej decyzji o wyszukaniu innego, lepiej brzmiącego ekwiwalentu oraz napisaniu krótkiego komentarza dotyczącego tego, jakie narzędzia oraz zasoby zostały wykorzystane do wykonania tego zadania. Metafory zostały w tekście wytłuszczone (zidentyfikowane), gdyż proces identyfikacji metafor, który jest tematem szeroko opisywanym w literaturze przedmiotu ${ }^{2}$, mógłby przesłonić główny cel badawczy, a studenci mogliby zbyt dużo czasu poświęcić temu zadaniu. Studenci mieli wybrać do analizy sześć fragmentów z dziesięciu tekstów wyekscerpowanych do niniejszego badania.

$\mathrm{Na}$ potrzeby niniejszego artykułu metaforę definiuje się tradycyjnie jako wyrażenie językowe, w którym dochodzi do przekształcenia standardowych znaczeń elementów składających się na to wyrażenie. Efektem tego procesu jest ukształtowanie nowego znaczenia. Przyjmuje się, że wyrażenia metaforyczne, zwłaszcza te skonwencjonalizowane, stanowią pewne odbicie procesów myślowych, potwierdzając tym samym znane od lat twierdzenie, że ję-

\footnotetext{
${ }^{2}$ Zob. np. metodę MIP, MIPVU.
} 
zyk jest „Zwierciadłem” rzeczywistości. Nie wprowadza się jednak tego aspektu do definicji samego terminu, a badania zostały ograniczone do poziomu tekstowego ${ }^{3}$.

\section{WYNIKI BADANIA}

Pewnym modyfikacjom zostały poddane w sumie 142 wyrażenia metaforyczne. Tylko 10 razy metafory zostały ocenione pozytywnie; 7 uczestników zdecydowało się na pozostawienie wyrażeń w pierwotnej formie. Oczywiście taki wynik może też być efektem tzw. syndromu czerwonego długopisu (Allen 297-318), który oznacza, że im więcej zmian zostanie wprowadzonych, tym lepiej zadanie zostanie ocenione przez innych i przez nauczyciela.

Wyrażenie economic insanity (org. obłęd ekonomiczny) zostało ocenione pięć razy pozytywnie i studenci zdecydowali się na pozostawienie tego wyrażenia w niezmienionej postaci. Swoją decyzję tłumaczyli tym, że występuje ono dostatecznie często w wynikach wyszukiwania Google (13 000 wyników), WebCorp Live (164 wyniki; wyszukiwarka Bing). Analiza wyników potwierdziła, że to wyrażenie jest używane w dyskursie politycznym. Osoby, które zdecydowały się na zmianę, zaproponowały następujące rozwiązania: economic chaos, economic crisis, economic uncertainty, economic decline, economic instability, economic meltdown, economic problems; economic downturn, economic recession, economic madness (...)

Kolejnym wyrażeniem, które studenci uznali za poprawnie przetłumaczone, było politicial fixation. Uznali, że i to wyrażenie występuje dość często w wynikach Google, zwłaszcza w tekstach na temat gospodarki: Google - 4220 wyników; WebCorp Live - 46 wyników (wyszukiwarka Bing). Inne alternatywne tłumaczenia tego wyrażenia (uznane przez większość studentów za lepsze) to: political obsession, political business, political matter, political activity, political turmoil. Oczywiście w tym przypadku należałoby także zanalizować semantyczną prozodię.

Innym powodem decyzji o pozostawieniu wyrażeniu w wersji tłumaczenia maszynowego było to, że studenci nie znaleźli lepszych ekwiwalentów i zdecydowali się na pozostawienie tych wyrażeń w ich pierwotnej wersji. Dotyczyło to takich wyrażeń, jak: nerwy bankowe, banki odzyskały oraz hired by loans. Jedna $\mathrm{z}$ osób napisała, że przekształcenie tych wyrażeń wymaga kreatywności od tłumacza. Te słowa mogą potwierdzać stwierdzenie

\footnotetext{
${ }^{3}$ Za Teresą Dobrzyńską i Wacławem Cockiewiczem.
} 
niektórych badaczy, że tłumaczenia maszynowego nie powinno się stosować do tekstów literackich czy publicystycznych. Warto jednak jeszcze raz podkreślić, że celem tego badania nie jest ocena jakości thumaczenia maszynowego sensu stricto, tylko analiza sposobu wykorzystania narzędzi oraz zasobów do korekty thumaczenia wyrażeń metaforycznych.

Sposób postępowania badanych można porównać do opisywanych w literaturze przedmiotu etapów postedycji (TAUS 2010), na które składają się m.in.: analiza (w tym porównywanie tekstu źródłowego z docelowym) oraz ocena jakości tłumaczenia, na której podstawie tłumacz podejmuje decyzję dotyczącą wprowadzenia ewentualnych zmian w tekście docelowym. W niniejszym artykule koncentrujemy się na analizie zachowania badanych przed podjęciem decyzji dotyczącej jakości tłumaczenia oraz modyfikacji wyrażeń metaforycznych oraz działań związanych z samym przekształcaniem analizowanych metafor.

Analiza raportów przesłanych przez studentów udowodniła, że działania zmierzające do poprawy wyrażeń metaforycznych (przetłumaczonych maszynowo) polegały głównie na:

1) ocenie jakości tłumaczenia, która odnosiła się do odpowiedzi na pytanie: czy wyrażenie metaforyczne jest zrozumiałe, używane i akceptowane w języku docelowym w danym typie dyskursu? (OCENA I DEC Y Z J A)

2) przekształceniu wyrażenia metaforycznego (E D Y C JA)

3) weryfikacji dokonanych zmian (WER Y F I K A C J A).

Dla potrzeb niniejszych badań wymienione aktywności zostały nazwane skrótowo: ocena i decyzja, edycja oraz weryfikacja. Każdy z etapów jest związany z daną strategią wyszukiwania informacji leksykalno-semantycznych. W większości przypadków (86 razy) studenci zdecydowali się na zastosowanie następujących kroków w kolejnych etapach zadania:

(OCENA I DECYZJA)

1. Określenie frekwencji, dystrybucji oraz semantycznej prozodii wyrażenia metaforycznego w języku docelowym (użyte zasoby oraz narzędzia: Google Advanced Search, NKJP, BNC-Web, Web-Corp Live, HASK)

(E D Y C J A)

2. Utworzenie listy najczęstszych kolokatów jednego z komponentów składającego się na wyrażenie metaforyczne (NKJP, BNC-Web, HASK) 
(W E R Y F I K A C J A)

3. Sprawdzenie frekwencji, dystrybucji oraz semantycznej prozodii zmodyfikowanego wyrażenia metaforycznego (Google Advanced Search, NKJP, BNC-Web, WebCorp Live).

Studenci sprawdzali w korpusach referencyjnych oraz zasobach Internetu, czy dane wyrażenie metaforyczne występuje w tekstach w języku docelowym: jak często i czy w tekstach dotyczących polityki i gospodarki. Następnie poszukiwali częstszego kolokatu jednego z elementów wyrażenia w korpusach referencyjnych i sprawdzali jego frekwencję oraz dystrybucję w zasobach Internetu.

W dziesięciu przypadkach studenci analizowali także wyrażenie w języku źródłowym. Określali jego frekwencję, dystrybucję oraz semantyczną prozodię.

Sześć razy podczas edycji studenci poszukiwali synonimów, nie kolokatów jednego $\mathrm{z}$ elementów wyrażenia metaforycznego, które stanowiłyby częstsze połączenia z drugim elementem wyrażenia. Używali wówczas innych narzędzi, takich jak Tezaurus, Wordnet oraz Sketch Engine (Similar Words).

Do oceny jakości tłumaczenia studenci wykorzystywali również słowniki języka ogólnego online. Poszukiwali znaczenia oraz zakresu użycia wyrażeń metaforycznych oraz ich komponentów. Wówczas można było wyróżnić następujące kroki:

(OCENA I DECYZJA)

1. Określenie znaczenia oraz zakresu użycia wyrażeń metaforycznych na podstawie definicji słownikowych (WSJP, Freeonline dictionary)

(E D Y C J A)

2. Poszukiwanie synonimów jednego z elementów wyrażenia, które stanowiłyby częstsze połączenia $z$ drugim elementem wyrażenia bądź utworzenie listy najczęstszych kolokatów jednego z komponentów składającego się na wyrażenie metaforyczne (NKJP, BNCWeb, HASK).

(W E R Y F I K A C J A)

3. Sprawdzenie frekwencji, dystrybucji oraz semantycznej prozodii zmodyfikowanego wyrażenia metaforycznego (Google Advanced Search, NKJP, BNCWeb, WebCorp Live).

Taki sposób poszukiwania danych leksykalnych wystąpił 25 razy.

Studenci przeszukiwali również korpusy paralelne do oceny tłumaczenia oraz edycji wyrażeń metaforycznych. 
(OCENA I DECYZJA)

1. Określenie znaczenia oraz zakresu użycia wyrażeń metaforycznych na podstawie korpusów paralelnych.

(E D Y C J A)

2. Poszukiwanie synonimów jednego z elementów wyrażenia, które stanowiłyby częstsze połączenia $z$ drugim elementem wyrażenia bądź utworzenie listy najczęstszych kolokatów jednego z komponentów składającego się na wyrażenie metaforyczne (NKJP, BNCWeb, HASK).

(W E R Y F I K A C J A)

3. Sprawdzenie frekwencji, dystrybucji oraz semantycznej prozodii zmodyfikowanego wyrażenia metaforycznego (Google Advanced Search, NKJP, BNCWeb, WebCorp Live).

Zanotowano 15 razy taki sposób poszukiwania oraz edycji i weryfikacji wyrażeń metaforycznych.

Studenci sięgali do słowników oraz korpusów paralelnych w sytuacji, kiedy ewentualna zmiana dotyczyła pojedynczego wyrazu, np. hangover $\rightarrow$ $k a c$, patologia $\rightarrow$ pathology. W tych przypadkach sprawdzali zakresy użycia tych dwóch leksemów. Co więcej, częściej sięgali do słowników obcojęzycznych czy korpusów paralelnych, aby sprawdzić znaczenie bądź tłumaczenie danego wyrażenia w języku polskim.

\section{PODSUMOWANIE}

Przeprowadzone badanie pokazało, że w większości studenci poszukiwali „lepszych” i częściej występujących ekwiwalentów wyrażeń metaforycznych, które wystąpiły w tekście źródłowym. W celu sprawdzenia, czy dane wyrażenie występuje w języku docelowym w dyskursie politycznym, sięgali głównie do zasobów Internetu. Wykorzystywali do tego wyszukiwarkę Google oraz aplikację WebCorp Live. Związane to jest także z tym, że w korpusach referencyjnych nie znajdywali wyników dla wybranych wyrażeń, gdyż są one charakterystyczne dla współczesnego dyskursu politycznego. Nie używali również korpusu specjalistycznego, np. korpusu tekstów prasowych, dostępnego w programie Sketch Engine. Jeśli mieli trudności ze znalezieniem lepszego rozwiązania, wówczas pozostawiali wyrażenie w niezmienionej postaci. Dodawali komentarz, że cały fragment należałoby sparafrazować, żeby brzmiał naturalnie w języku docelowym. Warto jednak zauważyć, 
że w większości przypadków narzędzia korpusowe (zwłaszcza konkordancje) były wykorzystywane do oceny jakości tłumaczenia oraz weryfikacji końcowej. Natomiast programy do wyszukiwania kolokacji były używane do edycji wyrażeń metaforycznych.

Ponadto okazało się, że studenci sięgali głównie do słowników języka ogólnego online, jeśli nie znali znaczenia wyrażenia oraz zakresu jego użycia. Ponadto chętniej sięgali do korpusów paralelnych, jeśli tłumaczenie odbywało się z języka angielskiego na język polski. Nie korzystali jednak z korpusów tworzonych na potrzeby zadania (tzw. DIY).

Ćwiczenie pokazało także studentom, że obecnie jest dużo dostępnych narzędzi i zasobów, z których mogą korzystać, aby usprawnić proces tłumaczenia. Pojawiają się coraz to nowe rozwiązania, funkcjonalności, które ułatwiają pracę tłumacza nie tylko w samym procesie tłumaczenia, ale także weryfikacji czy nawet tworzenia glosariuszy czy własnych korpusów.

Badanie również udowodniło, że studenci mają swoje przyzwyczajenia oraz indywidualne preferencje dotyczące stosowanych strategii oraz wykorzystywanych zasobów oraz narzędzi. Świadczą o tym następujące dane: ośmiu uczestników zdecydowało się na zastosowanie tylko jednego sposobu poszukiwania rozwiązań do oceny oraz modyfikacji i weryfikacji wszystkich wyrażeń metaforycznych. Jedna osoba używała jedynie korpusów paralelnych do wykonania tego zadania. To także pokazało studentom, że nie ma jednej najskuteczniejszej strategii wyszukiwania informacji czy też najlepszego narzędzia analizy tekstu. Różne obrane strategie mogą prowadzić do podobnych bądź tych samych wyników.

\section{BIBLIOGRAFIA}

Allen, Jeffrey. „Post-editing”. Computers and Translation: A Translator's Guide, red. Harold Somers, John Benjamins Publishing Company, 2003, ss. 297-318.

Brożyna-Reczko, Małgorzata. „O metaforze choroby w polskim i angielskim prasowym dyskursie politycznym”. Tekst i Dyskurs, vol. 11, 2018, ss. 351-369.

Cockiewicz, Wacław. Metaforyka Leśmiana. (Analiza lingwistyczna). Wydawnictwo Akademickie, 2011.

Delizée, Anne. „A global rating scale for the summative assessment of pragmatic translation at Master's level: An attempt to combine academic and professional criteria". Perspectives on Translation Quality, red. Ilse Depraetere, De Gruyter, 2011, ss. 9-24.

Dobrzyńska, Teresa. Mówiąc przenośnie. Studia o metaforze. Instytut Badań Literackich, 1994.

Dybiec-Gajer, Joanna. „Kompetencje profesjonalnego tłumacza a kształcenie i sukces zawodowy. Model kompetencji EMT z perspektywy polskich tłumaczy w Parlamencie Europejskim”. 
Kompetencje tłumacza. Tom dedykowany prof. dr hab. Elżbiecie Tabakowskiej, red. Maria Piotrowska, Artur Czesak, Aleksander Gomola, Sergiy Tyupa, Tertium, 2012, ss. 167-193.

Zmierzyć przekład. Z metodologii oceniania $w$ dydaktyce przekładu pisemnego. Universitas, 2013

Gouadec, Daniel. Translation as a Profession. John Benjamins Publishing Comapany, 2007.

EMT Expert Group. Competences for Professional Translators, Experts in Multilingual and Multimedia Communication. 2009, ec.europa.eu/info/ sites/info/files/ emt_competences_ translators_en.pdf. Dostęp 30.09.2020.

Koglin, Arlene. „An empirical investigation of cognitive effort required to post-edit machine translated metaphors compared to the translation of metaphors". The International Journal for Translation \& Interpreting Research, vol. 7, $\mathrm{nr}$ 1, 2015, ss. 126-141.

Pęzik, Piotr. „NKJP w warsztacie tłumacza”. Narodowy Korpus Języka Polskiego, red. Adam Przepiórkowski, Mirosław Bańko, Rafał L. Górski, Barbara Lewandowska-Tomaszczyk, Wydawnictwo Naukowe PWN, 2012, ss. 301-311.

. „Paradygmat Dystrybucyjny w Badaniach Frazeologicznych. Powtarzalność, Reprodukcja i Idiomatyzacja”. Metodologie językoznawstwa. Ewolucja języka, ewolucja teorii językoznawczych, red. Piotr Stalmaszczyk, Wydawnictwo Uniwersytetu Łódzkiego, 2013.

Raido, Vanessa Enriquez. Translation and Web Searching. Routledge, 2014.

Sekuła, Justyna. „Kształcenie zawodowych kompetencji tłumaczy tekstów prawnych i prawniczych w ramach studiów podyplomowych". Comparative Legilinguistics, vol. 25, 2016, ss. $95-108$

TAUS 2010, TAUS the language data network, www.taus.net/academy/best-practices/posteditbest-practices/machine-translation-post-editing-guidelines. Dostęp 2.10.2019.

\section{NARZĘDZIA CYFROWE W DYDAKTYCE PRZEKŁADU: \\ ZASOBY LEKSYKALNE ORAZ NARZEDZIA KORPUSOWE DO EDYCJI TEKSTU}

Streszczenie

Niniejszy artykuł stanowi przegląd zasobów leksykalnych oraz narzędzi korpusowych przydatnych do oceny, edycji oraz weryfikacji przetłumaczonych tekstów. Dodatkowo zawiera opis badania pilotażowego, którego celem było opisanie zachowania studentów w sytuacji, gdy należy ocenić oraz dokonać modyfikacji leksykalno-stylistycznej wyrażenia metaforycznego przetłumaczonego maszynowo. Analizie poddano jedynie to, jakich narzędzi oraz zasobów studenci używali i na jakim etapie zadania. Ćwiczenie zostało wykonane w ramach zajęć na studiach magisterskich, kierunek: przekładoznawstwo - technologie tłumaczeniowe.

Słowa kluczowe: metafora; thumaczenie maszynowe; kompetencja wyszukiwania informacji; korpus; słownik. 
DIGITAL TOOLS IN TRANSLATION DIDACTICS: LEXICAL RESOURCES AND CORPUS TOOLS FOR TEXT EDITING

\section{S u m m a r y}

This article deals with the use of lexical resources and corpus tools to evaluate, edit, and verify already translated texts. Additionally, it provides a description of a pilot study whose purpose was to describe students' behaviour in a situation where machine-translated metaphorical phrases should be evaluated and corrected. The analysis focuses on identifying the lexical resources and tools that were most frequently used at every stage of the task. The exercise was conducted during a course on translating technologies for MA students of translation studies.

Key words: metaphor; machine translation; information literacy; corpus; dictionary. 